\title{
Four spider species of the families Theridiidae, Araneidae, and Salticidae (Arachnida: Araneae) new to Thailand
}

\author{
Wimolwan Chotwong ${ }^{1} \&$ Akio Tanikawa ${ }^{2}$ \\ ${ }^{l}$ Entomology and Zoology Group, Plant Protection Research and Development Office, \\ Department of Agriculture, Chatuchak, Bangkok 10900, Thailand \\ E-mail:wimolwanc@hotmail.com \\ ${ }^{2}$ Laboratory of Biodiversity Science, School of Agriculture and Life Sciences, The University of Tokyo, \\ 1-1-1, Yayoi, Bunkyo-ku, Tokyo, 113-8657 Japan \\ E-mail:dp7a-tnkw@j.asahi-net.or.jp
}

\begin{abstract}
Four spider species, Chrysso trimaculata Zhu, Zhang \& Xu 1991, Argiope dang Jäger \& Praxaysombath 2009, Cyclosa cucurbitoria (Yin, Wang, Xie \& Peng 1990), and Thiania bhamoensis Thorell 1887, are newly recorded from Thailand.
\end{abstract}

Key words - taxonomy, new records, Chrysso trimaculata, Argiope dang, Cyclosa cucurbitoria, Thiania bhamoensis, Thailand

\section{Introduction}

After examining spider specimens collected from various parts of Thailand, we recognized following four species being new to the Thai spider fauna: Chrysso trimaculata Zhu, Zhang \& Xu 1991, Argiope dang Jäger \& Praxaysombath 2009, Cyclosa cucurbitoria Yin, Wang, Xie \& Peng 1990, and Thiania bhamoensis Thorell 1887. They are recorded from Thailand for the first time and redescribed. Chrysso trimaculata was described from Fujian and has been known from southern part of China and Taiwan (Yoshida 1993, Song et al. 1999). Argiope dang was described from Laos and previously has been known exclusively from there (Jäger \& Praxaysombath 2009, 2011). Cyclosa cucurbitoria was described from Yunnan and has been known from the southern part of China (Yin et al. 1990, Song et al. 1999). Thiania bhamoensis was described from Burma and is commonly known as fighting spiders in South East Asia (Thorell 1887, Rashid \& Azirun 1992). Thus, all four species have never been recorded from Thailand.

The voucher specimens used in this study are deposited in Entomology and Zoology Group, Plant Protection Research and Development Office, Department of Agriculture, Bangkok, Thailand.

We wish to express our hearty thanks to Dr. Tadashi Miyashita, The University of Tokyo, for his critical reading of the manuscript of this paper. Our heartfelt thanks are also due to Mr. Ondra Ramone Košulič for offering specimens used in this study. We are deeply indebted to Mrs. Wipada Vangsilabutr and Mr. Jirapat Bangtha who helped with the field work, and to Khunying Prapaisri Pitakpaivan, advisor to permanent secretary, Ministry of Agriculture and Cooperatives, for her assistance in this work. This study is based upon work supported in part by a grant from the Agriculture Research and Development Agency (ARDA), Ministry of Agriculture and Cooperatives, Thailand.

\section{Chrysso trimaculata Zhu, Zhang \& Xu 1991}

(Figs. 1-2, 7-8)

Chrysso trimaculata Zhu, Zhang \& Xu 1991, p. 174, figs 8-12 [male holotype from Fujian, China, deposited in Hebei Educational College, not examined]; Yoshida 1993, p. 31, figs 13-14; Zhu 1998, p. 58, figs. 31A-F; Song et al. 1999, p. 107, figs. $50 \mathrm{~F}-\mathrm{G}, \mathrm{O}-\mathrm{P}$.

Specimens examined. 1우, Phu Toei waterfall, 24-XI-

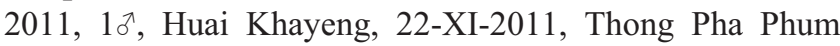
District, Kanchanaburi Province, Thailand. W. Chotwong leg.

Description. Based on 1 우 and $10^{\lambda}$ from Thong Pha Phum, Thailand. Coloration and markings in alcohol. Carapace and sternum are yellowish brown, labium pale yellow. Abdomen, yellowish brown with three black spots (Fig. 2). Leg I is the longest and Leg III the shortest.

Measurement. Body 우 3.13/ 万 2.15 long, carapace 우 1.07 / 万 0.95 long; 우 1.00 / 万 0.95 wide. Length of legs [우 / 중 tarsus + metatarsus + tibia + patella + femur $=$ total]: I, $0.40+1.93+1.47+0.47+1.73=6.00 / 0.73$ $+1.77+1.50+0.45+1.65=6.10 ;$ II, $0.60+1.13+$ $0.73+0.40+1.20=4.06 / 0.37+0.80+0.80+0.33$ $+1.23=3.53$; III, $0.43+0.67+0.63+0.33+0.40=$ $2.46 / 0.33+0.47+0.50+0.27+0.80=2.37 ; \mathrm{IV}, 0.53$ 


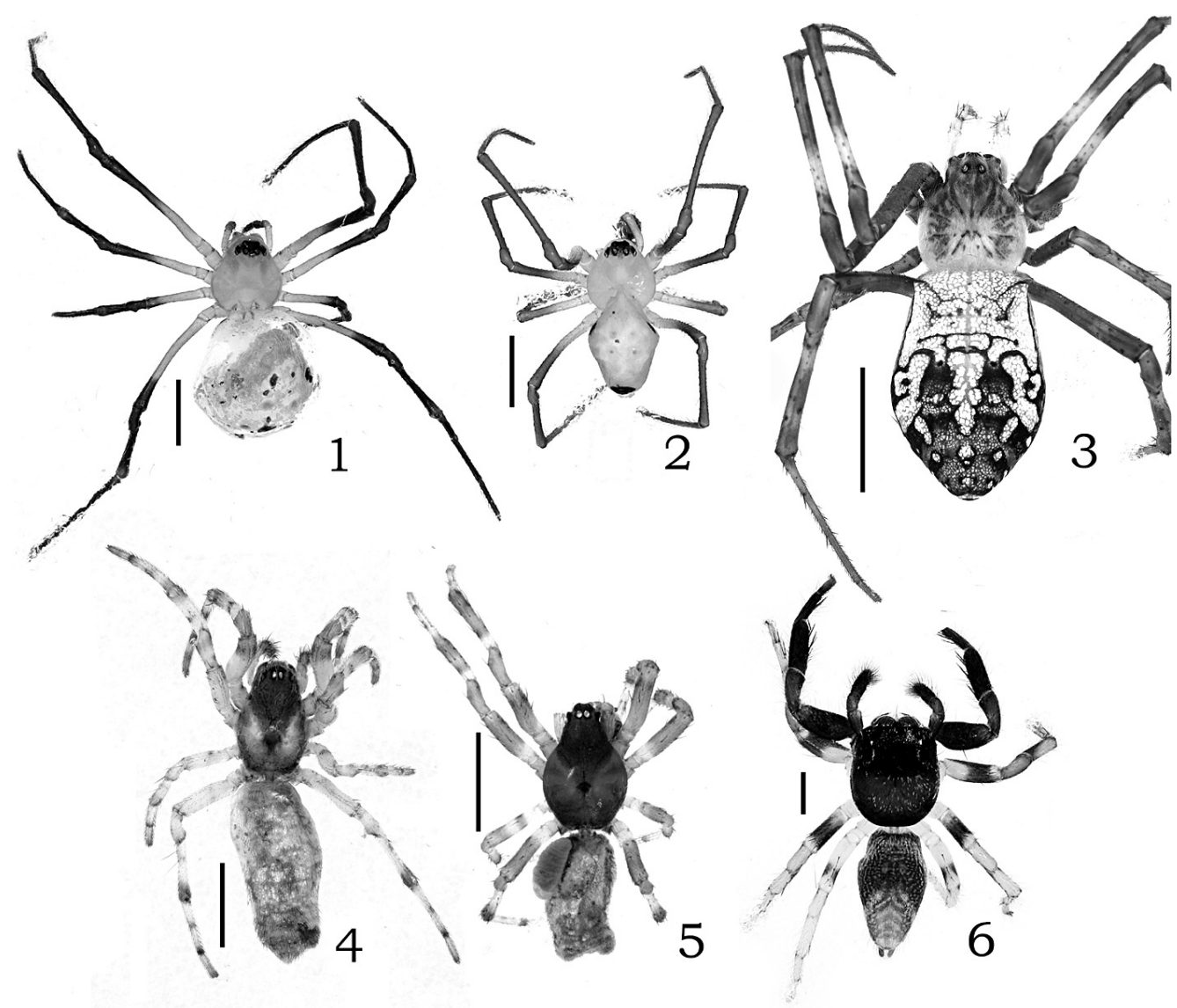

Figs. 1-6. Habitus. 1, Chrysso trimaculata Zhu, Zhang \& Xu 1991, female from Kanchanaburi Province; 2, same, male; 3, Argiope dang Jäger \& Praxaysombath 2009, female from Nakron Pathom Province; 4, Cyclosa cucurbitoria Yin, Wang, Xie \& Peng 1990, female from Rayong Province; 5, same, male; 6, Thiania bhamoensis Thorell 1887, female from Ratchaburi Province. Scales $=1 \mathrm{~mm}(1-2$, 4-6); $5 \mathrm{~mm}(3)$.

$+1.20+0.60+0.40+1.67=4.40 / 0.57+1.23+$ $1.00+0.33+0.97=4.10$. Abdomen $+9.00 /$ § 1.45 long,

우 1.73 / ठ 1.00 wide.

Female and male. Carapace almost as long as wide [length/width +1.07 / o 1.00]. Median ocular area wider than long [length/width o $0.71 /$ o 0.77 ]; wider in front than behind [anterior width / posterior width 우 1.17 / o 1.18]. Cheliceral furrow with 2 promarginal teeth, retromargin without tooth. Labium wider than long [length/width 우 $\left.0.58 / \delta^{\lambda} 0.65\right]$. Sternum almost as long as wide [length/ width ㅇ 0.93 / § 0.95]. Length of leg I/length of carapace 우 5.61 / 万 6.42. Male palp (Fig. 7): embolus long and bent, basal part kidney shaped. Abdomen longer than wide [length/width 우 $\left.1.16 / \delta^{7} 1.45\right]$. Female genitalia (Fig. 8): epigynal opening oblong and wide.

Remarks. This species is distinguished from other Thai Chrysso species by having three black spots on abdomen, a wide and oblong epigynal opening, and a long and bent embolus of male palp (Figs. 2, 7-8).

Distribution. Thailand, China, Taiwan.
Argiope dang Jäger \& Praxaysombath 2009

(Figs. 3, 9-10)

Argiope dang Jäger \& Praxaysombath 2009, p. 36, figs. 38-51. [holotype male (SMF 58757) from Vang Vieng, Laos, preserved in the Research Institute Senckenberg, Frankfurt am Main, not examined.]; Jäger \& Praxaysombath 2011, p. 25, figs. $53^{-} 56$.

Specimens examined. 3우, butterfly dome, Kasetsart University, Kamphaeng Saen District, Nakron Pathom Province, 16-XI-2011. 1우, cassava field, Huaypong District, Rayong Province, 21-VI-2011. All the specimens were collected by O. R. Košulič and W. Chotwong in Thailand.

Description. Based on 1 우 from Nakron Pathom, Thailand. Coloration and markings in alcohol. Carapace is yellowish brown, anteriorly darker, sternum pale yellow brown, labium pale yellow, chelicerae yellowish brown with a black marking. Abdomen bright silver with dark color marking especially in the posterior half (Fig. 3).

Measurement. Measurements in parentheses indicate the 

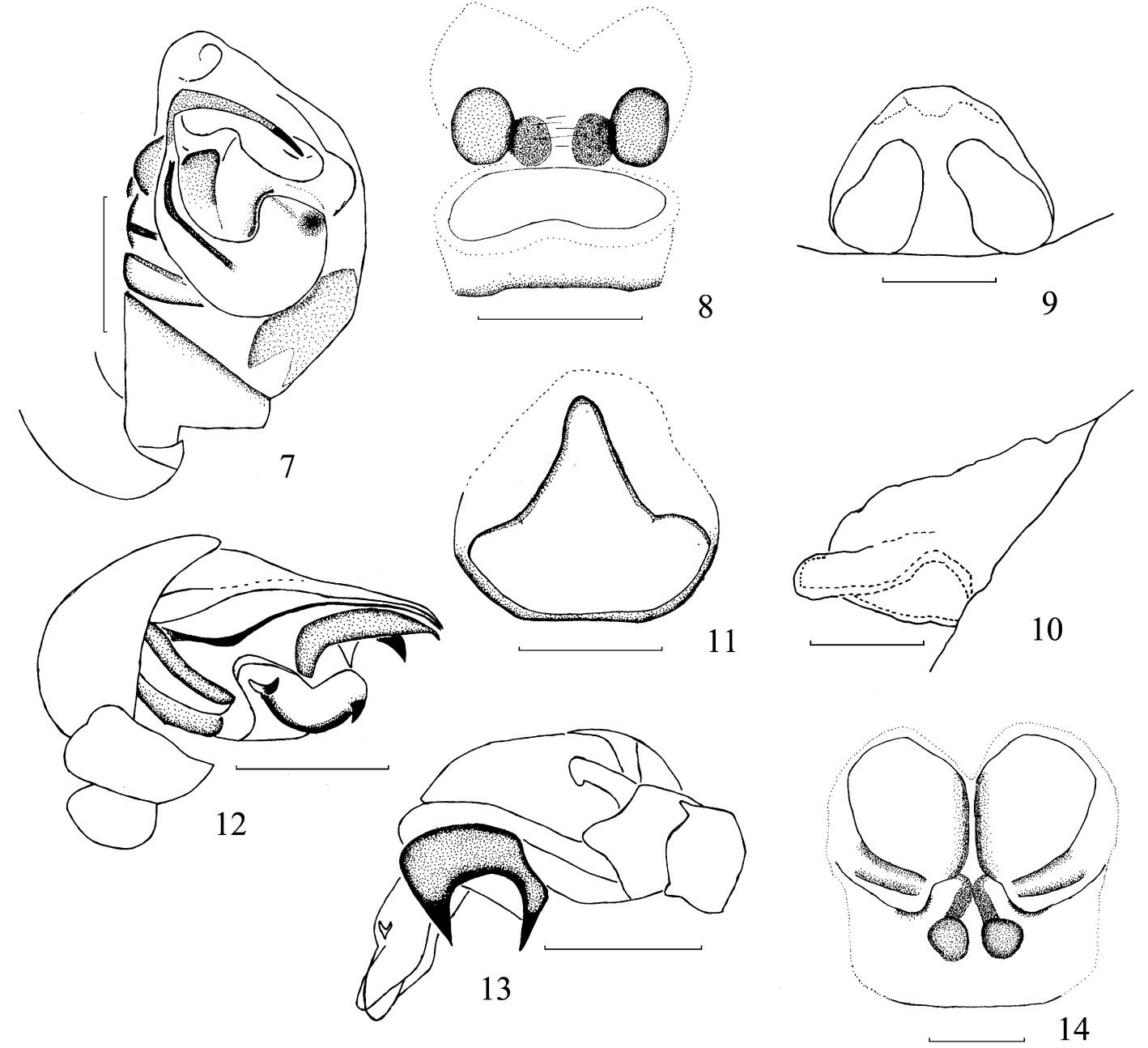

Figs. 7-14. Copulatory organs. 7, Chrysso trimaculata Zhu, Zhang \& Xu 1991 from Kanchanaburi Province, left male palp, ventral view; 8, same, epigyne, ventral view; 9, Argiope dang Jäger \& Praxaysombath 2009 from Nakron Pathom Province, epigyne, posterior view; 10, same, lateral view; 11, Cyclosa cucurbitoria Yin, Wang, Xie \& Peng 1990 from Rayong Province, epigyne, ventral view; 12, same, left male palp, prolateral view; 13, same, retrolateral view; 14, Thiania bhamoensis Thorell 1887 from Ratchaburi Province, epigyne, ventral view. Scales $=0.25 \mathrm{~mm}$.

range among specimens examined. Body 13.47 (11.4713.73) long, carapace 4.67 (4.67-5.07) long; $4.00\left(4.00^{-}\right.$ 4.67) wide. Length of legs [female: tarsus + metatarsus + tibia + patella + femur $=$ total]: $\mathrm{I}, 1.33+8.27+6.40+$ $2.53+8.27=26.8 ;$ II, $1.33+7.87+6.27+2.53+$ $8.00=26 ;$ III, $1.20+4.27+3.07+1.73+5.73=16.00$; IV, $1.47+7.20+4.80+2.40+8.40=24.27$. Abdomen 9.20 (7.47- 9.20) long, $6.00(5.07-6.00)$ wide.

Female. Carapace slightly longer than wide [length/ width $1.17\left(1.00^{-1.17)]}\right.$. Median ocular area almost as long as wide [length/width $1.07(1.07-1.15)]$; wider behind than in front [anterior width/posterior width $0.69(0.69-0.77)]$. Cheliceral furrow with 4 promarginal and 3 (3-4) retromarginal teeth. Labium wider than long [length/width $0.66(0.54-0.67)]$. Sternum slightly wider than long [length/ width $0.90(0.82-0.97)]$. Length of leg I/length of carapace 5.74 (5.74-6.77)]. Abdomen longer than wide [length/ width $1.53(1.47-1.55)]$. Female genitalia (Figs. 12-15): epigyne long and projecting ventrally.
DNA barcoding. The sequencing data of mt-COI of the specimen used for the description are available in DDBJ/ EMBL/GeneBank databases. The accession number is AB753452. The method for DNA analysis is the same as in Tanikawa (2012).

Remarks. The present species resembles Argiope catenulata in general appearance, but can be distinguished from the latter by having a projecting epigyne (Figs. 12-13).

Distribution. Thailand, Laos.

Cyclosa cucurbitoria (Yin, Wang, Xie \& Peng 1990) (Figs. 4-5, 11-13)

Eustala cucurbitoria Yin, Wang, Xie \& Peng 1990, p. 65, figs. 163-168 [female holotype from Yunnan, China, deposited in Hunan Biology Research Institute, not examianed].

Cyclosa cucurbitoria Yin \& Gong 1996, p. 74, figs. 9-11; Yin et al 1997. p. 231, figs. $144 \mathrm{a}^{-}$; Song et al. 1999. p. 264, figs. $156 \mathrm{D}-\mathrm{E}, 158 \mathrm{P}-\mathrm{Q}, 160 \mathrm{~N}$. 
Specimens examined. 1우 $10^{\lambda}$, cassava field, Huaypong District, Rayong Province, 9-III-2012. 1 ${ }^{\widehat{\lambda}}$, cassava field, Nong Tak Ya District, Kanchanaburi Province, 17-VIII2011. All the specimens were collected by W. Chotwong in Thailand.

Description. Based on 1 우 and $1 \sigma^{\Uparrow}$ from Kanchanaburi, Thailand. Coloration and markings in alcohol. Female: carapace pale brown, head region darker, sternum has turbid brown pattern, labium dark brown, abdomen pale brown with dark brown irregular marking. Male: carapace and sternum dark brown, abdomen pale brown.

Measurement. Measurements in parentheses indicate the second specimen examined. Body 우 3.80 / ๙ 2.50 (3.00) long, carapace 우 1.40 / ð 1.25 (1.50) long; 우 0.87 / ठ 0.60 (1.00) wide. Length of legs [ㅇ / $\delta$; tarsus + metatarsus + tibia + patella + femur $=$ total $]:$ I, $0.35+0.80+0.90+$ $0.55+0.75=3.35 / 0.37+0.70+0.67+0.40+0.80=$ 1.20 ; II, $0.25+0.65+0.75+0.50+0.60=2.75 / 0.33$ $+0.43+0.60+0.40+0.67=2.43$; III, $0.30+0.35+$ $0.40+0.35+0.55=1.95 / 0.13+0.23+0.43+0.27$ $+0.53=1.59 ;$ I, $0.40+0.55+0.80+0.50+0.85=$ $3.10 / 0.13+0.40+0.70+0.33+0.60=2.16$. Abdomen 우 2.00 / Љ 1.20 (1.50) long, 우 1.07 / đ 0.60 (0.70) wide.

Female and male. Carapace longer than wide [length/width 우 $1.61 /$ 乃 2.08 (1.50)]. Median ocular area wider than long [length/width 우 0.85 / § $0.67(0.64)$ ]; wider front than behind [anterior width/posterior width 우 1.86 / § 1.71 (1.75)]. Cheliceral furrow with 4 promarginal teeth and 2 retromarginal teeth in female, no tooth in male. Labium wider than long [length/width 우 0.57 / 주 0.57 (0.73). Sternum longer than wide [length/width 우 1.37 / $\delta^{7} 1.36$ (1.30). Length of leg I/length of carapace + 2.39 / क 0.96 (1.09). Male palp (Figs. 10-11): embolus filiform, median apophysis with two sharp points (Fig. 11). Abdomen longer than wide [length/width 우 1.87 / ð 2.00 (2.14)], with a pair of tubercles at the posterior end. Female genitalia (Fig. 9): epigyne with a triangle plate.

Remarks. This species is distinguished from other Thai Cyclosa species by epigyne with a triangular plate (Fig. 9), and median apophysis having two sharp points (Fig. 11).

Distribution. Thailand, China.

\section{Thiania bhamoensis Thorell 1887}

(Figs. 6, 14)

Thiania bhamoensis Thorell 1887, p. 357 [syntypes from Burma, deposited in Museo Civico di Storia Naturale di Genova, not examined]; Prószyński 1983, p. 284, figs. 5-6; Prószyński 1984, p. 144; Żabka 1985, p. 452, figs. 616-624; Peng et al. 1993, p. 238, figs. $848-854$; Song et al. 1999 , p. 562, figs. 320K, 322B, 330E; Davis et al. 2005, p. 245, figs. 1a-h, 2i-m, 3n-o; Prószyński \& Deeleman-Reinhold 2010, p.181, figs. $142-147$.

Marptusa oppressa Thorell 1891, p.114.

Thiania oppressa Simon 1901, p. 588.
Euophrys chiriatapuensis Tikader 1977, p. 206, figs. 26A-B; Tikader \& Biswas 1981, p. 101, figs. 183-184.

Specimens examined. 3우, grassland in Photharam District, Ratchaburi province, Thailand, 18-VIII-2011, W. Chotwong leg.

Description. Based on 1 우 from Thailand. Coloration and markings. Carapace mostly dark brown covered with lustrous scale like hairs behind anterior eye row and around thorax. Chelicera brown. Sternum bright brown. Leg I blackish brown. Leg II: distal half of femur yellowish, distal half of patella and tibia dark brown, metatarsus and tarsus bright brown. Leg III and IV paler than leg II. Each leg with lustrous scale like hairs on patella and tibia. Abdomen with marking by lustrous scale like hairs.

Measurement (in mm). Measurements in parentheses indicate the range among specimens examined. Body 5.67 (5.13-5.67) long, carapace 2.67 (2.53-2.73) long; 2.20 (2.07-2.20) wide. Length of legs [tarsus + metatarsus + tibia + patella + femur $=$ total]: I, $0.53+1.27+1.27+$ $1.00+1.67=5.74 ;$ II, $0.47+0.80+0.87+0.80+$ $1.33=4.27$; III, $0.53+1.07+0.87+0.73+1.13=$ 4.33 ; IV, $0.53+1.13+1.20+0.80+1.27=4.93$ Abdomen 2.87 (2.47-2.87) long, 1.73 (1.47-1.73) wide.

Female. The cephalothorax is flattish, slightly longer than wide [length/width $1.21(1.19-1.32)]$. Length of eye field/length of carapace $0.47\left(0.46^{-0.49)}\right.$, Length of eye field/width $0.76(0.74-0.76)$, width of eye field III/width of eye field I $0.97\left(0.93^{-0.97)}\right.$, distance between eye field I and II/distance between eye field II and III 1.43, width of eye field III/width of carapace $0.73(0.73-0.77)$. Cheliceral furrow with 2 promarginal and 1 retromarginal teeth. Labium wider than long [length/width $0.75\left(0.75^{-0.90)}\right]$. Sternum slightly longer than wide [length/width $1.16\left(1.16^{-}\right.$ 1.21)]. Legs I slightly swollen and longer than the others; length of leg I/length of carapace $2.15\left(1.88^{-2.15)}\right.$ ]. Abdomen longer than wide [length/width 1.66 (1.61-1.68)]. Female genitalia (Fig. 16): epigyne with a pair of large depressions divided by a narrow median septum.

Remarks. This species can be easily distinguished from the other Thai jumping spiders by the flattened body with a lustrous marking and the shape of the epigyne, having a pair of large depressions.

Distribution. Thailand, China, Vietnam, Pakistan, India, Myanmar, Sumatra, Bali, Hong Kong, Philippines, Indonesia, Borneo, New Guinea, Sulawesi, Sri Lanka, Malaysia, and Hawaii.

\section{References}

Davis, S., Sudhikumar, A. V., Jose, K. S. \& Sebastian, P. A. 2005. New record of the salticid spider Thiania bhamoensis Thorell (Araneae: Salticidae) from Kerala, India with its redescription and field notes on behavior. J. Bombay Nat. Hist. Soc., 102: 245-249.

Jäger, P. \& Praxaysombath, B. 2009. Spider from Laos: New species and new records (Arachnida: Araneae). Acta Arachnol., 58: 36-39.

Jäger, P. \& Praxaysombath, B. 2011. Spiders from Laos with fortythree new records and first results from the provinces Bolikhamsay 
and Champasak (Arachnida: Araneae). Acta Arachnol., 61: 9-31.

Peng, X. J., Xie, L. P., Xiao, X. Q. \& Yin, C. M. 1993. Salticids in China (Arachniuda: Araneae). Hunan Normal Univ. Press, 270 pp.

Prószyński, J. 1983. Redescriptions of types of Oriental and Australian Salticidae (Aranea) in the Hungarian Natural History Museum, Budapest. Folia Ent. Hung., 44: 283-297.

Prószyński, J. 1984. Atlas rysunkow diagnostycznych mniej znanych Salticidae (Araneae). Wyzsza Szkola Rolniczo-Pedagogiczna, Siedlcach, 2: 1-177.

Prószyński, J. \& Deeleman-Reinhold, C. L. 2010. Description of some Salticidae (Araneae) from the Malay Archipelago. I. Salticidae of the Lesser Sunda Islands, with comments on related species. Arthropoda Selecta, 19: 153-188.

Rashid, N. Y. \& Azirun, M. S. 1992. Agonistic behaviour of male fighting spiders (Thiania bhamoensis). Nature Malaysia, 17: 121123.

Simon, E. 1901. Histoire naturelle des araignées. Paris, 2: 381-668.

Song, D. X., Zhu, M. S. \& Chen, J. 1999. The Spiders of China. Hebei Sci. Technol. Publ. House, Shijiazhuang, 640 pp.

Tanikawa, A. 2012. Further notes on the spiders of the genus Dolomedes (Araneae: Pisauridae) from Japan. Acta Arachnol., 61: 11-17.

Thorell, T. 1887. Viaggio di L. Fea in Birmania e regioni vicine. II. Primo saggio sui ragni birmani. Ann. Mus. Civ. Stor. Nat. Genova, 25: 5-417.

Thorell, T. 1891. Spindlar fran Nikobarerna och andra delar af sodra Asien. Kongl. Svenska. Vet.-Acad. Handl., 24(2): 1-149.

Tikader B. K. 1977. Studies on spider fauna of Andaman and
Nicobar islands, Indian Ocean. Rec. Zool. Surv. India., 72: 206207, f 26A-B.

Tikader, B. K. \& Biswas, B. 1981. Spider fauna of Calcutta and vicinity: Part-I. Rec. Zool. Surv. India, Occ. Pap., 30: 1-149.

Yin, C. M. \& Gong, L. S. 1996. Four orb-weaver spiders of the family Araneidae from Hunan Province of China (Arachnida: Araneae). Acta Sci. Nat. Univ. Norm. Hunan, 19: 72-76.

Yin, C. M., Wang, J. F., Xie, L. P. \& Peng, X. J. 1990. New and newly recorded species of the spiders of family Araneidae from China (Arachnida, Araneae). In: Spiders in China: One Hundred New and Newly Recorded Species of the Families Araneidae and Agelenidae. Hunan Normal Univ. Press, pp. 1-171.

Yin, C. M., Wang, J. F., Zhu, M. S., Xie, L. P., Peng, X. J. \& Bao, Y. H. 1997. Fauna Sinica: Arachnida: Araneae: Araneidae. Science Press, Beijing, xiii +460 pp.

Yoshida, H. 1993. East Asian species of the genus Chrysso (Araneae: Theridiidae). Acta Arachnol., 42: 27-34.

Żabka, M. 1985. Systematic and zoogeographic study on the family Salticidae (Araneae) from Viet-Nam. Annls Zool. Warsz., 39: 197485.

Zhu, M. S. 1998. Fauna Sinica: Arachnida: Araneae: Theridiidae. Science Press, Beijing, xi +436 pp.

Zhu, M. S., Zhang, W. S. \& Xu, Y. J. 1991. Notes on three new species and two new records of Theridiidae from China (Araneae: Theridiidae). Acta Zootaxon. Sin., 16: 172-180.

Received October 26, 2012 / Accepted November 14, 2012 